\title{
A Nasopharyngeal Human Infestation Caused by Linguatula serrata Nymphs in Van Province: A Case Report
}

\author{
Van Yöresinde Linguatula serrata Nimflerinin Neden Olduğu Bir Nazofarengeal İnsan
}

İnfestasyonu: Bir Olgu Sunumu

\author{
Hasan Yılmaz' ${ }^{1}$ Zeynep Taş Cengiz'1 Mutalip Çiçek², Ahmet Cumhur Dülger ${ }^{3}$ \\ 'Department of Parasitology, Medical Faculty, Yuzuncu Yil University, Van, Turkey \\ 2Department of Microbiology, Medical Faculty, Dicle University, Diyarbakır, Turkey \\ ${ }^{3}$ Division of Gastroenterology, Department of Internal Medicine, Medical Faculty, Yuzuncu Yil University, Van, Turkey
}

\begin{abstract}
The reason for the presentation of this case is that Linguatula serrata, a parasite rarely encountered in humans, was found in a patient in Van province. The patient, who was 26 years old, lived in Erciş a town in Van province, East Turkey. She was admitted to the Outpatient Clinic of Infectious Diseases of Erciş Government Hospital with a complaint of coughing a few worms about $4 \mathrm{~cm}$ long from the oral cavity, and also sore throat, partial voice loss and vomiting. The polyclinic doctor suspected that the worm was a parasite but he could not make a diagnosis, and the patient was referred to Health Research and Training Hospital, Yüzüncü Yıl University. The parasite was examined in the Parasitology Laboratory and it was observed that this parasite was the nymph of $L$. serrata whose mouth was surrounded with four hooks and had approximately 90 body segments with small hooks. No medical treatment was given to the patient except that gargling with saline solution was recommended. As a result, we think that physicians should consider L. serrata infestation in patients applying to health foundations with complaints such as pharyngitis accompanied by pharyngeal pain, coughing, sneezing and vomiting.
\end{abstract}

(Turkiye Parazitol Derg 2011; 35: 47-9)

Key Words: Linguatula serrata, human, Van, Turkey

Received: 12.02 .2010

Accepted: 17.02.2011

\section{ÖZET}

Bu olgunun sunum nedeni insanlarda nadiren görülen Linguatula serrata'nın Van yöresinde bir hastada belirlenmesidir. Türkiye'nin doğusunda olan Van'ın, Erciş ilçesinde yaşayan vakamız 26 yaşındaydı. Hasta, öksürme ile yaklaşık 4 cm uzunluğunda ağızdan çıkan birkaç kurtçuk ve ayrıca boğaz ağrısı, ses kaybı ve kusma gibi şikayetlerle Erciş Devlet Hastanesi Enfeksiyon Hastalıkları Polikliniğine başvurmuştur. Poliklinik doktoru kurtçuğun parazit olduğundan şüphelenmesine rağmen teşhis koyamamış ve hastayı Yüzüncü Yıl Üniversitesi Araştırma ve Uygulama Hastanesine sevk etmiştir. Parazit bu hastanenin Parazitoloji Laboratuarında incelendi ve ağız etrafında dört çengel ve küçük çengellere sahip yaklaşık 90 vücut segmenti olan bu parazitin, L. serrata'nın nimfi olduğu anlaşıldı. Hastaya ilaç tedavisi uygulanmadı ve sadece tuzlu su ile gargara önerildi. Sonuç olarak farengeal ağrının eşlik ettiği faranjitis, öksürük, hapşırma ve kusma gibi şikayetler ile sağlık kuruluşlarına başvuran hastalarda, doktorların L. serrata infestasyonunu da dikkate almaları gerektiği kanaatindeyiz.

(Turkiye Parazitol Derg 2011; 35: 47-9)

Anahtar Sözcükler: Linguatula serrata, insan, Van, Türkiye

Geliş Tarihi: 12.02.2010 Kabul Tarihi: 17.02.2011

This study is presented in $16^{\text {th }}$ National Congress on Parasitology which was held in Adana between 1 and 7 November 2009.

Address for Correspondence/Yazışma Adresi: Dr. Zeynep Taş Cengiz, Department of Parasitology, Medical Faculty, Yuzuncu Yil University, Van, Turkey Phone: +90 4322150470 Fax: +90 4322167519 E-mail: ztas72@yahoo.com

doi:10.5152/tpd.2011.12 


\section{INTRODUCTION}

The phylum Pentastomida includes a group of parasites classified between the arthropods and annelids. Linguatula serrata, belonging to Pentastomida, is a worm-like parasite that lives mainly in the respiratory passages of carnivorous reptiles, birds, and mammals. Larval development takes place within an intermediate host, which ingests embryonated eggs from the sputum or feces of an infected definitive host. Fish, rodents, sheep, goats, cattle, deer, horses or rabbits may be intermediate hosts. The adult form of the parasite can be found in the nasal passages, frontal sinuses and tympanic cavity of carnivorous mammals such as the dog, wolf, fox, and cats, which are definitive hosts. The nymphs and adults of the parasites are rarely encountered in humans, and the larvae can be encountered in various organs such as liver, rarely in kidneys, eyes and the wall of intestines (1-6).

L. serrata has a cosmopolitan distribution in humans. The infections have been reported in Asia, America, Europe, Russia, Africa and some the Middle East and Arab countries (2, 4-12). The infection is acquired by ingesting raw vegetables or water contaminated with eggs of the parasite or by consuming uncooked infected liver or visceral lymph nodes of herbivorous mammals $(1,2,5)$. When infected raw meat is eaten, the nymphs settle into the liver and visceral lymph nodes and may attach to nasopharyngeal mucous membranes. In addition, the nymphs may also return from the stomach to the pharynx. Then, the parasites in the pharynx enter the nasal sinuses, and females lay eggs. The attached nymphs provoke a pharyngitis accompanied by pharyngeal pain, coughing, sneezing and vomiting. Dyspnea, dysphagia, headache, photophobia, and exophthalmia may also be present. When larvae or nymphs die, they are absorbed or may calcify. Encysted nymphs rarely produce clinical symptoms (1-4).

The reason for the presentation of this case is that $L$. serrata, a parasite rarely encountered in humans, was encountered in a patient in Van province.

\section{CASE REPORT}

The patient, who was 26 years old, lived in the Erciş town of the Van region, East Turkey. She was admitted to the Infectious Diseases Service of Erciş Government Hospital with complaints of coughing out a worm about $4 \mathrm{~cm}$ long from oral cavity. Besides coughing, a burning sensation in the nasopharyngeal mucous membranes, sore throat, loss of voice, vomiting and fatigue were among the patient's complaints, and she reported that the complaints began three days earlier. The doctor of the Outpatient Clinic of Infectious Diseases suspected that the worm was a parasite but he could not make a diagnosis of the parasite and referred the patient to Health Research and Training Hospital, Yüzüncü Yıl University. The parasite was examined in the Parasitology Laboratory of this hospital. The parasite, whose mouth was surrounded with four hooks and had approximately 90 body segments with small hooks (Figure 1), as indicated in the literature (1-3), was identified as the nymph of $L$. serrata. Medical treatment was not given to the patient and only gargling with saline solution was recommended. The patient explained to the doctor that she did not eat raw meat. No para- site was encountered in the oral cavity of the patient at the control examination performed one month later. However, the patient stated that the burning sensation persisted in the nasopharyngeal mucous membranes.

\section{DISCUSSION}

Parasitic diseases are very important in Turkey as well as in developing countries, especially in tropical and subtropical regions. Due to suitable environmental conditions, parasites are widespread in the Van province. Also, the, low socio-economic status of the inhabitants of the province facilitates the distribution of the parasites, which is supported by the result of previous studies performed in Van province (13).

L. serrata has been detected in various human organs in the studies made around the world. It has been reported that this parasite was found in the nasopharynx of a 20-year-old man in Egypt (10), in the throat of a 28-year-old woman in Tehran, Iran (6), in the anterior chamber of the eye (nymph of the parasite) of an 8-yearold girl in central Mississippi, USA (12), in the eye (nymph of the parasite) of a 34-year-old woman in Guayaquil, Ecuador (5), in a calcified nodule on the liver (nymph of parasite) of a 62-year-old man in North Carolina, USA (7), in the liver (nymph of the parasite) of a 15-year-old man in Bashkortostan, Russia (9), in a lung nodule (larvae of the parasite) of a 42-year-old man with AIDS in Apulia, Italy (11), and in parenchymal tubercles of the small intestine wall (larvae of the parasite) of a 3-year-old girl in Zhejiang, China (8). L. serrata infestation in Turkey has rarely been determined. The first infestation with nymphs of the parasite was reported by Unat and Şahin in 1959. In this case, the nymph has been obtained in the nasal cavity and crypts of tonsils by the researchers (2). The second case was determined in the choleduct (nymph of the parasite) of a 40-year-old man in Bursa (14).

Nasopharyngeal infestation has been reported in Turkey (2), Egypt (10) and Iran (6). This infestation is produced by ingestion of nymphs or third-instar larvae together with food, such as raw or semi-raw intermediate host liver or lymph nodes (1-3, 5). Although our patient stated that she did not eat raw or semi-raw meat, it is known that women in the Van province habitually taste meals before or during cooking, as do women in other parts of Turkey. As the infestation of the patient with the nymph of the parasite was not possible by another route, tasting meals with

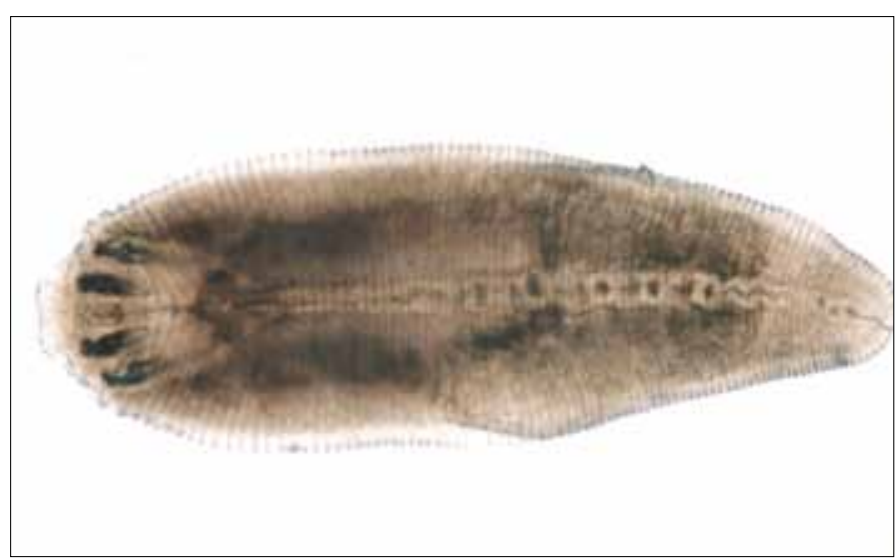

Figure 1. L. serrata nymph determined in the patient (X32) 
meat before or during cooking could explain how our patient got infected. This idea is supported by the fact that the parasite was not detected in other persons of the family who ate the same meals.

In previous studies, the parasites were usually detected at histopathologic examinations, surgery or autopsy, mainly in the nasopharynx, eye, intestine, liver and lungs, but our patient explained that she had coughed up the parasite and was admitted to the hospital. Coughing, a burning sensation in nasopharyngeal mucous membranes, sore throat, loss of voice, vomiting and fatigue were detected in the patient. These symptoms could be provoked by the attached nymphs. These findings obtained were similar to the findings of the other authors $(2,6,10)$.

As a result, we think that physicians should consider L. serrata infestation in patients attending health foundations with complaints such as pharyngitis, accompanied by pharyngeal pain, coughing, sneezing and vomiting.

\section{Acknowledgement}

We thank Dr. Tahir Seçkinli who works in the Infectious Diseases Service of Erciş Government Hospital, Van and provided us with the clinical pictures of the patient.

\section{Conflict of Interest}

No conflict of interest was declared by the author.

\section{REFERENCES}

1. Özçelik S. Pentastomiosis. Özcel MA, Özbel Y, Ak M. eds. Özcel'in Tıbbi Parazit Hastalıkları. İzmir: Türkiye Parazitoloji Derneği Yayınları, Yayın No: 22; 2007. p. 901-3.

2. Unat EK, Yücel K, Altaş K, Samastı M. Unat'ın Tıp Parazitolojisi. Insanın Ökaryonlu Parazitleri ve Bunlarla Oluşan Hastalıkları.
İstanbul: İstanbul Üniversitesi Cerrahpaşa Tıp Fak. Vakfı Yayınları. Yayın No: 15; 1995. p. 223-7.

3. Markell EK, Voge M, John DT. Medical Parasitology. Seventh Edition. Philadelphia: W.B. Saunders; 1992. p. 359-60.

4. Drabick JJ, Pentastomiasis. Rev Infect Dis 1987; 9: 1087-94. [CrossRef]

5. Lazo RF, Hidalgo E, Lazo JE, Bermeo A, Llaguno M, Murillo J, et al. Ocular linguatuliasis in Ecuador: Case report and morphometric study of the larva of Linguatula serrata. Am J Trop Med Hyg 1999; 60: 405-9.

6. Maleky F. A case report of Linguatula serrata in human throat from Tehran, central Iran. Indian J Med Sci 2001; 55: 439-41.

7. Baird JK, Kassebaum LJ, Ludwig GK. Hepatic granuloma in a man from North America caused by a nymph of Linguatula serrata. Pathology 1988; 20: 198-9. [CrossRef]

8. Lai C, Wang XQ, Lin L, Gao de C, Zhang HX, Zhang YY, et al. Imaging features of pediatric pentastomiasis infection: a case report. Korean J Radiol 2010; 11: 480-4. [CrossRef]

9. Lukmanova Gl, Gumerov AA. A case of concomitant hepatic lesion in a child with cystic hydatid disease and Arthropoda larva (nymph). Med Parazitol 2007; 1: 54-5.

10. Morsy TA, Sharkawy IM, Lashin AH. Human nasopharyngeal linguatuliasis (Pentasomida) caused by Linguatula serrata. J Egypt Soc Parasitol 1999; 29: 787-90.

11. Pampiglione S, Maggi P, Scattone A, Sollitto F. A nodular pulmonary lesion due to Linguatula serrata in an HIV-positive man. Parassitologia 2001; 43: 105.

12. Rendtorff RC, Deweese MW, Murrah W. The occurrence of Linguatula serrata, Pentastomid, within the Human Eye. Am J Trop Med Hyg 1962; 762-4.

13. Yılmaz H, Akman N, Göz Y. Distribution of intestinal parasites in two societies with different socio-economic status in Van. E J M 1999; 4 16-9.

14. İşler O, Tınar R. Bir insanın koledok kanalında Linguatula serrata (Frohlich, 1789) nimfi. Türkiye Parazitol Derg 1993; 17: 108-11. 